\title{
MACHADO DE ASSIS AND BRAZILIAN LITERARY INDEPENDENCE: TOWARD A POSTCOLONIAL NATIONAL AESTHETIC ${ }^{1}$
}

\author{
G. Reginald Daniel \\ University of California \\ Santa Barbara, Califórnia, Estados Unidos
}

\begin{abstract}
As a mulatto who was both black and white, yet neither, Machado de Assis developed a keen sensitivity to what Santiago refers to as "o entre-lugar", that is to say, the liminal or in-between space that shapes human existence. Machado gave artistic expression to this phenomenon in a manner that encompassed broader contradictions and questions of multiplicity and ambiguity in terms of Brazil's national literary identity. His writings do not display a national consciousness or brasilidade (Brazilianness) expressed through the use of racial types, external descriptions of local flora, fauna, or idioms, as was the case with the anticolonial writings of many of his contemporaries and successors, which fostered a superficial cultural essentialism. In keeping with Bhabha's conceptualtization of postcolonial thought, Machado searched for a radical nationalism generated within a liminal space that contested the terms and territories of both colonialism and anticolonial nationalism. He sought to achieve this without belonging to a neocoloniality that reduced Brazilian intellectual and cultural production to second-order copies incapable of articulating any originality. Rather, Machado elucidated a mark of differentiated repetition that borrowed from the finest, most enduring exemplars of European literature yet transformed these into something uniquely Brazilian.
\end{abstract}

Keywords: Machado de Assis, criticism; Brazilian literature; national identity in literature, colonialism; postcolonial discourse.

${ }^{1}$ This article borrows material in DANIEL, Machado de Assis: multiracial identity and the Brazilian novelist. 
MACHADO DE ASSIS E A INDEPENDÊNCIA LITERÁRIA

BRASILEIRA: EM DIREÇÃO A UMA ESTÉTICA NACIONAL PÓS-COLONIAL

Resumo: Como um mulato que era preto e branco, ou nenhum dos dois, Machado de Assis desenvolveu uma sensibilidade aguçada para o que Santiago se refere como "o entre-lugar", isto é, o limiar ou espaço-entre que molda a existência humana. Machado deu expressão artística a este fenômeno de uma forma que englobava contradições e questões de multiplicidade e ambiguidade mais amplas em termos de identidade literária nacional do Brasil. Seus escritos não apresentam uma consciência nacional ou brasilidade, expressos através do uso de tipos raciais, descrições de locais externos, flora, fauna, ou expressões idiomáticas, como foi o caso com os escritos anticoloniais de muitos de seus contemporâneos e sucessores, que fomentaram um essencialismo cultural superficial. De acordo com a conceptualização do pensamento pós-colonial de Bhabha, Machado procurou um nacionalismo radical gerado dentro de um espaço limiar que contestou os termos e territórios tanto do colonialismo como do nacionalismo anticolonial. Ele procurou conseguir isso sem pertencer a uma neocolonialidade que reduziu a produção intelectual e cultural brasileira a cópias de segunda ordem, incapazes de articular qualquer originalidade. Em vez disso, Machado elucidou uma marca de repetição diferenciada que pegou emprestada dos melhores e mais duradouros exemplares da literatura europeia e transformou isso em algo exclusivamente brasileiro.

Palavras-chave: Machado de Assis, crítica; literatura brasileira; identidade nacional na literatura; colonialismo; discurso pós-colonial.

\section{The critical legacy}

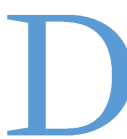

uring the nineteenth and early twentieth centuries, the measure of a country's development and modernity was defined by the extent to which it had developed a unique national culture. The Brazilian 
intelligentsia specifically interpreted this to mean literature (and a literate public) $-^{2}$ literacy and modernity perceived as related, if not equal. Machado de Assis, as Brazil's most prominent writer of the nineteenth and early twentieth centuries, devoted considerable thought to the question of national cultural identity, particularly in terms of forging a Brazilian literary aesthetic. ${ }^{3}$ However, his status as a representative Brazilian author has been the subject of extensive debate.

Some of Machado's contemporaries such as Sílvio Romero (1851-1914) criticized him for failing to convey a sense of his Brazilian surroundings. According to Romero, writers' style should conform to their temperament, providing a direct, immutable correspondence and imperceptible line between environmental, physical, and cultural traits as well as historical circumstances. Machado was a mulatto, but according to Romero, he did not reflect this in his writings. Romero insists that Machado's novels are failures because his pessimism, skepticism, and irony are incompatible with an authentic Brazilian and mestiço soul. Instead, they are insipid, artificial attempts to imitate the humor of the eighteenth-century English novel. Moreover, Romero criticizes Machado's novels because his protagonists are not authentic expressions of the national character. In sum, Romero argued that Machado delayed rather than advanced the development of an authentically Brazilian literature by his mindless imitation of foreign models and indifference toward Brazilian reality. ${ }^{4}$

Kristal and Passos point out that Romero's evaluation of Machado de Assis had significant ramifications on the history of Brazilian literary criticism in general, and Machadian studies in particular. ${ }^{5}$ For example, José Veríssimo (1857-1916) acknowledged Machado's genius, but believed his writings fell short of any criteria one would consider nationalist, i.e., the main tenets of Romero's work. Later, Veríssimo would somewhat recant and writes that Machado conveyed, albeit not explicitly, a profound and perceptive

\footnotetext{
2 MAZAMA, The Eurocentric discourse on writing, p. 6, 8.

3 BAPTISTA, Em nome do apelo do nome, p. 43-63, 99-114; CANDIDO, Formação da literatura brasileira, vol. 2, p. 115-16; SCHWARZ, Que horas são?, p. 29-48; SCHWARZ, Misplaced ideas, p. xv, 100-6.

${ }^{4}$ ROMERO, Machado de Assis, p. 12, 57, 66-67, 79, 80, 99-114, 121-23, 153, 161-7, 184, 255-6, 266-7, 285-6.

${ }^{5}$ KRISTAL and PASSOS, Machado de Assis and the question of Brazilian national identity, p. 21-22.
} 
understanding of the Brazilian soul and Brazilian society with an aptitude for synthesis that placed his writings among the great universal masterpieces. ${ }^{6}$

Writers Mario de Andrade (1893-1945), José Lins do Rego (1901-1957), Aurélio Buarque de Holanda Ferreira (1910-1989), and Cassiano Ricardo (18951974), as well as social scientist Gilberto Freyre, were less willing than Romero to dismiss completely the significance of Machado. Andrade admired Machado's literary genius and virtuosity, but did not consider him a representative Brazilian author. In addition, he argues that it is impossible to feel any affection for an author who holds such a heartless view of humanity. Lins do Rego acknowledged Machado's genius and the universality of his writings. Moreover, he recognized Machado's unmatched ability at conveying the mysterious and dark recesses of the human psyche. However, he was critical of Machado's contempt for humanity and lack of compassion for human suffering, as well as his unwillingness to provide any answers to society's most pressing concerns. ${ }^{8}$

Buarque de Holanda states that Machado "was lacking...a sentiment...of love for the land, the local setting, and his people."9 Ricardo adds that Machado was a "great Brazilian writer with an anti-Brazilian spirit."10 Finally, Freyre considered Machado an elitist and pretentious mulatto who denied his racial and class background, and everything Brazilian, including the national landscape. Kristal and Passos point out that Freyre sums up the deep Brazilian ambivalence toward Machado when he insists that Alencar is the true father of Brazilian letters, notwithstanding Machado's unparalleled mastery of European literary forms. ${ }^{11}$

Lúcia Miguel Pereira agreed with Romero's deterministic framework. However, she disagreed with Romero's perception that Machado was not a representative Brazilian author because of his supposed failure to convey a

\footnotetext{
${ }^{6}$ VERÍSSIMO, Estudos brasileiros, p. 304, 310, 314.

${ }^{7}$ ANDRADE, Aspectos da literatura brasileira, p. 89-90, 94, 101, 103, 105.

${ }^{8}$ REGO, Conferências no prata, p. 45, 92, 97, 100.

${ }^{9}$ HOLANDA, Linguagem e estilo de Machado de Assis, p. 13, 55.

10 RICARDO, Marcha para Oeste, p. 274-5.

${ }^{11}$ FREYRE, Reinterpretando José de Alencar, p. 115-6, 117, 118, 119.
} 
sense of brasilidade (Brazilianness) in his writings. ${ }^{12}$ Instead, she considered Machado:

...the first great Brazilian author....His writings are universal in thought, Brazilian in sensibility" [...] In truth, Machado de Assis was not simply a Brazilian author, but also a carioca, who was not merely national but also regional [...] Not the type of regionalism that was preoccupied with local color, but rather,[...] a regionalism of sensibility. ${ }^{13}$

Kristal and Passos indicate that Miguel Pereira helped pave the way for other studies that viewed Machado as a representative Brazilian author. For example Astrojildo Pereira states:

It has been repeated many times - and with good reason - that Machado de Assis is the most universal of our writers; I should point out that what is missing in this statement is that he is also the most national, the most Brazilian of all. I would also add, without intending to make a play on words, that one quality comes from the other: that is to say, he is much more national than universal and much more universal than national. Other writers have more local setting; none has conveyed a more profound understanding of the Brazilian people. ${ }^{14}$

\section{Anticolonial nationalism and literary independence}

Candido points out that Machado de Assis was the culmination of the lengthy quest for Brazil's literary emancipation from external models. As a nation that originated as a colony, Brazil sought to establish an autonomous cultural identity distinct from that of its colonial past. Nationalist sentiment in Brazil, i.e., the sense of separateness from Portugal and the Portuguese, had been

12 PEREIRA, Machado de Assis, p. 332.

${ }^{13}$ Idem, p. 331, 332, 335. Linguists maintain that "Carioca" derives from the Tupi word "kara'i oca," roughly translated as "white house" or "house of whites," a term indigenous people used to refer to the houses built by the Portuguese. Eventually, the inhabitants of Rio de Janeiro took on the designation "Carioca" to refer to their city (DANIEL, Machado de Assis, p. 258).

14 PEREIRA, A., Interpretações, p. 15. 
growing since at least the middle of the seventeenth century. ${ }^{15}$ The struggle for cultural independence gained momentum between 1750 and 1880 with the gradual shift from mere duplication of European forms to growth of local themes. Along these same lines, Reis highlights Alencar's attempts to compose a vast mural of Brazil, writing urban, Indianist, rural, and historical novels that sketched a portrait of the nation. Writers such as Alencar sought to give their works a specifically Brazilian character. Such a project matched perfectly with romantic local color and nationalism, both of which coincided with the idealization that was normative in contemporary literature. This corresponded to the political task undertaken beginning with independence in 1822 and completed during the Second Reign (1840-1889). ${ }^{16}$

Yet prior to the nineteenth century, the white ruling class's imitation of Europe did not constitute a problem. In fact, the Brazilian elite's association with the culture of Portugal and Western Europe, along with its social distance from the masses, composed largely of blacks and mulattoes, was a principal means of legitimating its dominance. It was primarily with political independence from Portugal in 1822 that tension between the local and the foreign escalated into a full-blown battle for supremacy. ${ }^{17}$ Machado did not, however, recommend that Brazilian writers reject foreign influences in the quest for literary independence. ${ }^{18}$ Rather, he struck out against the lingering cultural dependency between the Brazilian intelligentsia and European models despite Brazil having gained political independence.

This dependency led to the elite's mindless, servile, and indiscriminate copying of European forms, which Machado referred to as a "plague that came from abroad and imposed itself upon Brazil's still unformed literary spirit, which as yet had no real consciousness of itself."19 Machado believed that "only a shadow of a literature had evolved, one without sustenance or ideals, false, and frivolous, consisting of poor imitations and bad copies." ${ }^{20}$ Instead, Machado

${ }^{15}$ CANDIDO, Formação da literatura brasileira, vol. 2, p. 115, 214, 369.

${ }^{16}$ REIS, The pearl necklace, p. 47.

${ }^{17}$ SCHWARZ, Misplaced ideas, p. 12-13.

18 CALDWELL, Machado de Assis, independence, liberty, p. 89-90.

19 ASSIS, Carta a José de Alencar, Obra completa, vol. 31, p. 89-90; CALDWELL, Machado de Assis, independence, liberty, p. 89-90.

${ }^{20}$ ASSIS, cit., p. 89-90. 
recommended borrowing from the finest, most enduring, and universal exemplars of European literature yet transforming them into something uniquely Brazilian. ${ }^{21}$

Machado's Oliveira Twist, a partial translation of Dickens's novel Oliver Twist (1838), which appeared in serialized form in O Jornal da Tarde, a periodical to which Machado frequently contributed articles, is an excellent case study of this phenomenon. The translation of a serial novel, which Machado initiated in the early part of 1870, provided him with the extra income he greatly needed. However, two months after he began publishing Oliveira Twist, a position as officer for the secretary of state presented itself. Machado immediately notified the editors of Jornal of his decision to stop the translation and accepted the official position. Because Machado had a better command of French than English (indeed some scholars question whether Machado possessed any knowledge of English), Maciel argues that he based his translation on a Dickens-authorized French translation by Alfred Gerardin.

Maciel, who conducted the first thorough examination of this work, argues that Machado's close relationship with the original text provided him with an opportunity to give voice to certain current cultural misconceptions regarding the value of all that is foreign as well as contemporary tendencies that insisted on a certain type of Brazilianness through the misappropriation of Dickens's novel. Too often regarded as hackwork originating solely in financial motivations, Maciel argues that this translation demonstrates an engagement with current themes and polemics. Through his work as a translator, one can detect a set of idiosyncratic decisions guided by different social and political norms. As Machado engages these norms, he imposes on Dickens's text modifications that ultimately reveal more about the translator and his position in nineteenth-century Brazil than about the text itself. This type of inquiry is essential in bringing light to Machado's deep engagement with Brazilian themes and perception of Brazilianness as not necessarily restricted to local color and issues. Machado was prompted by the necessity to turn the foreign into something less strange and to provide readers with the experience of recognizing their own culture in the context of another cultural. Consequently, he transformed Oliver Twist into a text that exists between two worlds, that of

${ }^{21}$ SANTIAGO, The space in-between, p. 60-63, 151-52; SCHWARZ, Que horas são?, ensaios, p. 29-48; SCHWARZ, cit., p. Xv, 100-6. 
the foreign and that of the local, Rio de Janeiro and London, a tale of two cites, so to speak. ${ }^{22}$

Candido argues that Machado's essay "Notícia da Atual Literatura Brasileira: Instinto de Nacionalidade" (Notice on the Present State of Brazilian Letters: An Instinctive Sense of Nationality, 1873) was a masterful articulation of the importance of cultural independence, while at the same time considering the advantages and disadvantages of developing local themes. In this essay, which was published in celebration of the fiftieth anniversary of Brazil's political independence, Machado considered it important to distinguish between political (or national) independence and literary independence:

This other independence [the literary] will not be achieved [like the former] in a single day, but gradually, so that it will be more lasting; it will not be the work of one or two generations; many generations will labor until it has been completely accomplished. ${ }^{23}$

In another essay, Machado states that "... [it] is much easier to regenerate a nation than it is to regenerate literature. Indeed, the latter will not be achieved in one fell swoop, as was the case with the Grito de Ipiranga, but rather, only through long-term and consistent effort". ${ }^{24}$

Thus, Machado spells out the challenge of developing a national literature. Although Machado was an advocate for creating a uniquely Brazilian literary aesthetic, his belief in a deep engagement with Brazilian themes and perception of brasilidade was not restricted to local concerns. He positions all that is national in constant dialogue with that which is foreign. Indeed, Merquior emphasizes that it was with Machado that Brazilian literature entered into a significant dialogue with the critical voices of Western literature. ${ }^{25}$ Moreover, Bhabha maintains that the "locality" of national culture is neither unified nor

22 MACIEL, Machado de Assis' Oliveira Twist, p. 11-20.

${ }^{23}$ ASSIS, Obra Completa, vol. 3, p. 801.

${ }^{24}$ Idem, p. 787. The "Grito de Ipiranga" (literally, the "Ipiranga Shout"), which is the defining moment of Brazil's independence, stands out in sharp contrast to the violent national independence movements in other parts of the Americas. On the banks of the Ipiranga river near the city of São Paulo, the regent Pedro (later Emperor Pedro I) simply issued his proclamation "independência ou morte!" ("liberty or death"), declaring and essentially achieving Brazil's independence from Portugal (September 7, 1822).

${ }^{25}$ MERQUIOR, De Anchieta a Euclides, p. 154. 
unitary in relation to itself, nor should it be viewed simply as "other" in relation to what is external. ${ }^{26}$ The boundary between internal and external necessarily involves a process of hybridity. National consciousness and culture essentially take place within liminal (or transnational) $\operatorname{spaces}^{27}$ "through which the meanings of cultural and political authority are negotiated." ${ }^{28}$ Schwarz believes that Machado's writings reflect these dynamics and their attendant complexities and tensions.

At the same time, Brazil's adoption of modern European liberalism, which posits autonomous actors, in a society so completely dependent on slavery, resulted in discontinuities that persistently exposed the nation's social inequalities. $^{29}$ The regime based on slavery and land ownership existed alongside the new phenomenon of industrial capitalism and a market economy. Liberalism could not be fully achieved because it diverged considerably from the many traditional social and economic features inherited from the colonial era that still remained. Consequently, for much of the nineteenth century, liberalism remained a "misplaced idea" in Brazil. ${ }^{30}$ Along these lines, Machado was concerned with how to examine and draw social meaning from the juxtaposition of the traditional and modern rather than simply the existence of the traditional within the modern. He revealed the interdependence of these phenomena that emerges out of "a history in which modernization rarely operated through the substitution of the traditional."31 Machado sought to render these partially integrated realities by means of what García Canclini refers to as "multitemporal heterogeneity," 32 which coexist within the same "national-cultural worlds."33

According to Schwarz, Machado's writings portray brasilidade precisely in mirroring the duality, multiplicity, and ambiguity produced by these social

\footnotetext{
${ }^{26}$ BHABHA, Introduction, p. 4.

${ }^{27}$ WHALEN, Introduction: rhetoric as liminal practice, p. 1.

${ }^{28}$ BHABHA, cit., p. 4.

${ }^{29}$ SCHWARZ, Misplaced ideas, p. 19-24; SCHWARZ, Ao vencedor as batatas, p. 12.

30 SCHWARZ, cit., p. 19-24.

${ }^{31}$ CANCLINI, Culturas híbridas, p. 72.

32 Ibidem.

${ }^{33}$ LUND, The impure imagination, p. 31.
} 
forces. Schwarz argues that one of the aesthetic expressions of this phenomenon is the humor and ironic detachment so prominent in Machado's writings, particularly his later works. ${ }^{34}$ This seeming anomaly, viewed as an English import, was one of the reasons that Machado was considered the least authentically Brazilian writer. Instead of following models of the French novel, as was customary at the time, Machado looked to eighteenth-century British fiction as one of his main sources of inspiration, particularly Sterne's Tristram Shandy. This helped him devise the ideal vantage point to scrutinize late nineteenth-century Brazil in all its absurdity and illogicality. ${ }^{35}$

Schwarz maintains that Machado conveyed these incongruities through his inversion and subversion of numerous contemporary narrative and intellectual conventions, particularly his abandonment of straightforward, chronological for psychological, fragmented, and diffuse (or "spatialized") narration based on experiential time, as well as his voluble, unpredictable, and unreliable narrators. This narrative innovation expresses Machado's desire to expose the hypocrisies, contradictions, and dysfunctionality of nineteenthcentury Brazil, particularly the Second Empire (1840-1889), and the pernicious ends those social forces served. Likewise, Gledson regards Machado's work as a faithful transcription of the Brazilian social order articulated with a daring and innovative narrative technique. Chalhoub concurs with this analysis and states that Machado's prose exposes the contemporary social, political, and economic reality. ${ }^{36}$

Yet some critics, such as Baptista, do not believe that Machado's writings and innovative narrative technique represent a direct, immediate, and specific correspondence with nineteenth-century social reality, which underscores his profound engagement in the nationalist project. ${ }^{37}$ Baptista contends that one can read Machado without any reference to spatiotemporal, national, sociocultural contexts. Indeed, if one removed the geographical descriptions of Rio de Janeiro from his novels, the stories could occur in any location.

\footnotetext{
${ }^{34}$ SCHWARZ, Um mestre na periferia do capitalismo, p. 41, 40, 168-72.

35 REIS, The pearl necklace, p. 3-4; ROUANET, The Shandean form: Laurence Sterne and Machado de Assis, p. 81-83.

${ }^{36}$ SCHWARZ, cit., p. 168-72; GLEDSON, The deceptive realism of Machado de Assis, p. 1-8; CHALHOUB, Machado de Assis, p. 50-58, 64-90, 131-39.

${ }^{37}$ BAPTISTA, O legado Caldwell, ou o paradigma do pé atrás, p. 150, 155; 2003, 117-131.
} 
Moreover, Baptista claims that Machado's unique narrative form is not derived from an attempt to reflect the contradictions and dysfunctions of the social order. Rather, it reflects Machado's need to establish his own originality in relation to his literary predecessors. Essentially, Baptista maintains that Machado's literary trajectory is not based on fashioning a national literature that takes Brazilian reality into account but a national literature that takes broader literary imperatives into consideration. ${ }^{38}$

\section{Brasilidade and the national instinct}

In any case, if earlier criticism characterized Machado as indifferent to Brazilian reality, this indifference, according to Baptista, cannot refer to Brazilian reality in its totality, but Brazilian reality as imposed by the national project derived from the Romantic imperative. ${ }^{39}$ Indeed, Machado was critical of writers of the Romantic tradition who merely sprinkled their writings with the names of local flora and fauna as a basis for authentic brasilidade. ${ }^{40}$ From his perspective, the "majestic scenes of American nature certainly offered great possibility for the poet and the novelist." ${ }^{41}$ Yet he posed the perennial dilemma of the artist - how to develop nativistic and national themes while remaining universal in appeal - which he eloquently articulated in "Notícia da Atual Literatura Brasileira: Instinto de Nacionalidade" (1873):

I must add that on this point there is at times expounded an opinion, which I consider erroneous, that the national psyche can only be recognized in those works that deal in local color and themes, a doctrine which to be

38 BAPTISTA, A formação do nome, p. 33-42, 98-9, 108-11.

${ }^{39}$ Idem, p. 31-33.

40 Jobim has pointed out that Machado's poems in his book Americanas (1875) do reflect local color and nativistic themes that were emblematic of the nationalist-romantic movement (JOBIM, Machado de Assis and Nationalism, p. 571-83). Nevertheless, what Machado criticizes is the singular focus on this aesthetic to the exclusion of images that convey greater depth, profundity, and universality. This is also evident in his frustration with the Indianist "craze" that swept Brazil as part of the Romantic Movement's search for a national symbol. His censure did not, however, reflect any disparaging attitude towards Native Americans, negation of the Native American contribution per se to Brazilian culture, or negative sentiments about the legitimacy of Native Americans as a source of inspiration for the literary imagination. For a more detailed discussion of this topic see DANIEL, Machado de Assis, p. 163-4.

${ }^{41}$ ASSIS, cit., p. 802-3. 
exact, would limit the basic foundation of our literature... National poets are not thus so because they have utilized in their verse a multitude of names referring to national birds and flowers; this indeed is the basis for a national lexicon, and nothing more...True, there is no doubt that a literature, especially a newly developing one, should principally nourish itself upon subjects provided by its native region; but an absolute dependence on this doctrine would lead only to impoverishment. What must be expected of a writer above all else, is a certain intimate feeling, if you will, for the essence of a particular nation and its people at a particular moment, even if that subject matter is distanced in space or time... ${ }^{42}$

Machado eschewed laborious external descriptions of Brazilian flora, fauna, and racial types, or the excessive use of an idiomatic lexicon typified by anticolonial nationalist writings seeking to affirm authentic brasilidade. He searched beneath the Brazilian epidermis, beyond the particularities of Brazilian language, culture, and physiognomy, where he captured what he called the national "instinct". His objective was to express a consciousness that defined nineteenth-century Brazil, but also linked the Brazilian psyche with an oversoul shared by all humanity. Borges writes, "Machado's imaginings of human motivation has revealed a Machado whose insights can speak to people and situations beyond Brazil." ${ }^{43}$ Similarly, Piza notes that Machado's writings demonstrate a "richness and relevance...to our own contemporary circumstances." 44

That said, Rio de Janeiro and by extension, national history and topography during the second half of the nineteenth century and the early twentieth century (i.e., the Second Empire and the early Republic), is the predominant setting of Machado's novels. Cony and other critics point out that Machado evokes the atmosphere of Tijuca, the gardens of Andraí, the opulent mansions of Botafogo and Laranjeiras, and the throngs of residents of Catete, Flamengo, and Gloria. He captures the hustle and bustle of the Centro (downtown area), its narrow and straight streets, which are inundated with carriages and pedestrians-particularly "Ouvidor Street" (The Listener or

\footnotetext{
${ }^{42}$ Idem, p. 803-7.

${ }^{43}$ BORGES, The relevance of Machado de Assis, p. 246.

${ }^{44}$ PIZA, The place of Machado de Assis in the present, p. 282.
} 
Gossip Street)-the neurological center of the city from which rumors, good and bad, disseminate, and for which reputations large and small were created and made to crumble. ${ }^{45}$ Machado also chronicles the Paraguayan War, Abolition, the demise of the Monarchy and the establishment of the Republic, as well as the social behavior of the times. ${ }^{46}$ Yet Cony calls attention to the fact that these phenomena are not presented as a panoramic catalogue of place names and external descriptions. ${ }^{47}$ Rather, they are composed of kaleidoscopic glimpses that are organically integrated into the narrative through the lives, experiences, and reactions of the characters. ${ }^{48}$

By setting his works in Rio de Janeiro, Machado immerses them in the epicenter of Brazil's transformation from a rural to an urban economy based on monetary and commercial relations. However, Astrojildo Pereira, reiterating Lucia Miguel Pereira's earlier statement with a slightly different framing, emphasizes that Machado's "carioca regionalism"49 is not limited to Rio de Janeiro in terms of its relevance. On the contrary, Rio de Janeiro was the capital, and thus the point of convergence, a summation, an index of the entire nation. ${ }^{50}$ If, however, Machado's spatiotemporal particulars render a Rio de Janeiro and Brazil that are both historical and temporal, he imbues them with a universality that transcends spacetime.

Bastide sums this up when he writes:

[...] I regard Machado de Assis as one of the greatest Brazilian landscape artists, one of those who imbued the art of landscaping in literature with an impulse similar, to that which was accomplished in a parallel fashion in painting, and that I shall describe, if you will allow me to use Mallarmé's

${ }^{45}$ CONY, Confluências, p. 43-4.

46 FISCHER, Geography and representation in Machado de Assis, p. 191-214; VAL, Geografia de Machado de Assis, p. 19-25; LOWE, The City in Brazilian Literature, p. 87, 89.

${ }^{47}$ CONY, cit., p. 43-4.

48 FISCHER, Geography and representation in Machado de Assis, p. 191-214; KRISTAL AND PASSOS, Machado de Assis and the question of Brazilian national identity, p. 17-20.

49 According to linguists, "Carioca" derives from the Tupi word "kara'i oca," roughly translated as "white house" or "house of whites", a term indigenous people used to refer to the houses built by the Portuguese. Eventually, the inhabitants of Rio de Janeiro rook on the designation "Carioca" to refer to their city; DANIEL, Machado de Assis, p. 258.

50 PEREIRA, A, Interpretações, p. 15. 
expression, as a presence, but an almost hallucinatory presence of an absence...the landscape appears to be absent...yet it is actually a palpitating presence. $^{51}$

\section{Toward a postcolonial national aesthetic}

Given the absence of explicit expressions of brasilidade typical of many of Machado's contemporaries and successors, some critics might suggest that his writings signify the prolongation or repetition of colonialism through other means. ${ }^{52}$ Consequently, they may be tempted to characterize Machado's writings as "neocolonial. ${ }^{\text {"53 }}$ Yet determining the validity of this characterization requires a more nuanced analysis of the concept neocolonial, and the related concept "postcolonial", in terms of their relationship with colonialism. Colonialism was the process by which European nation-states reached global economic, military, political, and cultural domination over "Others" through conquest, direct control and settlement of their lands, and the distant control of their resources. ${ }^{54}$ Williams and Chrisman point out that the dismantling of West European colonial empires through anticolonial struggles, which began in the late eighteenth and early nineteenth centuries, provided an opportunity for newly independent countries (e.g., Brazil) to cast off the shackles of Western colonial domination and exploitation and develop genuine postcolonial societies. $^{55}$

Yet by implying that colonialism has ended, the term postcolonial also often lacks a political analysis of post-independence power relations. Indeed, it became apparent that the West had merely relinquished colonial domination and exploitation as its primary means of control (although this was not

\footnotetext{
${ }^{51}$ BASTIDE, Machado de Assis, paisagista, p. 1.

52 SHOHAT and STAM, Unthinking Eurocentrism, p. 1-54.

${ }^{53}$ BAPTISTA, Em nome do apelo do nome, p. 45-63, 99-111; CALDWELL, Machado de Assis, independence, liberty, p. 89; CANDIDO, On literature and society, p. 129-30, 135; SANTIAGO, The space-in-between, p. 151-52; SCHWARZ, Um mestre na periferia do capitalismo, p. 9-13; Misplaced ideas, p. xv, 101-3.

${ }^{54}$ SHOHAT and STAM, cit., p. 1-54.

55 WILLIAMS and CHRISMAN, Colonial discourse and post-colonial theory, p. 1-19.
} 
absent). ${ }^{56}$ Instead, dominative colonial structures were increasingly juxtaposed with - or replaced by - neocolonial ones that supported hegemonic forms of control. ${ }^{57}$ Shohat and Stam argue that these social forces thus maintained Western influence through a complex interweaving of economic, political, military, ideological, cultural dynamics, and hierarchical power relations. This involved patterns of selective inclusion and incorporation of opposition as well as interventionist politics in the post-independence era. ${ }^{58}$

These ambiguities and contradictions notwithstanding, the term postcolonial is applicable to Machado's quest for Brazil's cultural-and more specifically literary-independence. He questioned West European culture as the dominant and unchallenged center of the world. Yet Machado was also critical of anticolonial nationalism, which sought and led to the dismantling of formal political colonial domination but spawned a superficial cultural essentialism and fundamentalism. Consequently, nationalist theories and narratives frequently ended up being mere imitations (and poor ones at that) of the colonialist discourses they supposedly contested. In keeping with Bhabha's conceptualtization of postcolonial thought - which implies going beyond colonialism and anticolonial nationalism - Machado searched for a radical nationalism ${ }^{59}$ generated within a hybrid or liminal space that Santiago refers to as the "space-in-between" (o entre-lugar), ${ }^{60}$ which "contests the terms and territories of both." ${ }^{61}$

Santiago believes that Machado endeavored to achieve this by elucidating a mark of differentiated repetition, a "duplicate with a difference" from European discourse in rewriting European themes and reconfiguring European forms by Brazilians. However, Machado sought to accomplish this without belonging to a neocoloniality that reduced intellectual and cultural production of the periphery to a second-order copy and the "blind alley of dependency and

\footnotetext{
${ }^{56}$ SHOHAT and STAM, cit., p. 1-54.

${ }^{57} \mathrm{OMI}$ and WINANT, Racial formation, p. 66-69, 84, 115, 148.

${ }^{58}$ SHOHAT and STAM, cit., p. 1-54.

59 PENNA, Antonio Candido's critical method, p. 215.

${ }^{60}$ SANTIAGO, O entre-lugar no discurso Latino-Americano, p. 19-26.

${ }^{61}$ BHABHA, Location of culture, p. 28, 207-8.
} 
incapable of articulating any originality."62 Rather, he affirmed the value of the text of the colonized culture in terms of the space-in-between as the basis for a national aesthetic wherein notions of "original" and "copy" are deconstructed. ${ }^{63}$ This necessarily involves a process of hybridity that not only mediates but also fractures and reframes the binary and oppositional hierarchy in which these concepts are traditionally constructed. ${ }^{64}$ Accordingly, the symbolic relationship between colonizer and colonized, the center and periphery is altered and operates in a more intricate manner. ${ }^{65}$ Furthermore, Santiago contends that this narration on the periphery retroactively has an impact on the text of the metropolis (or center), thus creating the possibility for a creative evaluation of the universality of the texts of the dominant culture. ${ }^{66}$

As a mulatto who was both black and white, yet neither, Machado developed a keen sensitivity to and appreciation of hybridity and liminality, that is to say, the space-in-between, as well as the accompanying duality, multiplicity, and ambiguity, which shaped human experience. He did not, however, project these phenomena in his writings by focusing on epidermal or parochial concerns, as did some of his contemporaries and successors who celebrated mestizaje and cultural syncretism, which have been central tenets in the formation of Latin American national identities and ubiquitous in Latin American culture and thought. ${ }^{67}$ Instead, Machado sought to give artistic expression to liminality and hybridity by grappling with broader contradictions and meta-dimensions of duality, multiplicity, and ambiguity. This encompassed among other things the productions of traditional and modern, social and behavioral processes, as well as forms of thought. ${ }^{68}$ Accordingly, Machado forged a national literary aesthetic that took both Brazilian reality and broader literary imperatives into consideration. This not only makes Machado's writings

\footnotetext{
${ }^{62}$ GAZZOLA and MIRANDA, Introduction, p. 3.

${ }^{63}$ ROCHA, Introduction, p. xxiii, xxxi; PENNA, cit., p. 33.

${ }^{64}$ LUND, cit., 29.

${ }^{65}$ BHABHA, cit., p. 36-39; SHOHAT AND STAM, cit., p. 38-44; PENNA, cit., p. 215.

${ }^{66}$ SANTIAGO, cit., p. 3.

${ }^{67}$ LUND, cit., p. 47-8.

${ }^{68}$ CANCLINI, cit., p. 14-15.
} 
both universal and Brazilian, but also makes him one of Brazil's and Latin America's most deft and agile practitioners in this undertaking.

\section{Works cited}

ANDRADE, Mario de. Aspectos da literatura brasileira. São Paulo, SP: Martins, 1974. ASSIS, Machado de. Obra completa (31 vols.). Vol. 31. Rio de Janeiro: W. M. Jackson Inc. Editôres, 1937.

Obra completa. 3 vols. Rio de Janeiro: Editora José Aguilar, 1962.BAPTISTA, BATISTA, Abel Barros. Em nome do apelo do nome. Lisbon: Litoral Edições, 1991.

A formação do nome: duas interrogações sobre Machado de Assis. Campinas, SP: UNICAMP, Universidade Estadual de Campinas, 2003.

O legado Caldwell, ou o paradigma do pé atrás. In: Santa Barbara Portuguese studies 1: 1994. p. 145-77.

BASTIDE, Roger. Machado de Assis, paisagista. Revista do Brasil 3, no. 29 Novembro, 1940, p. 1-14.

BHABHA, Homi K. Introduction: Narrating the nation. In: Nation and narration. Homi K. Bhabha (ed.). New York: Routledge, 1990.

Location of culture. New York: Routledge, 1994. ASHCROFT, Bill Gareth Griffiths, and TIFFIN, Helen (ed.). New York: Routledge, 1995.

BORGES, Dain Edward. The relevance of Machado de Assis. In: SOUZA, Jessé and SINDER, Valter (ed.). Imagining Brazil. Lanham, MD.: Lexington Books, 2007, p. 23551.

CALDWELL, Helen. Machado de Assis, independence, liberty. In: UCLA Semana de Arte Moderna symposium (1922-1972): commemorating the 50th anniversary of the Semana de Arte Moderna in São Paulo and the 150th anniversary of Brazilian independence, February 7-12, 1972, Claude L. Hulet (ed.), UCLA. 1972, p. 89-99.

CANCLINI, Néstor García. Culturas híbridas. Mexico City: Grijalbo, 1989.

CANDIDO, Antônio. Formação da literatura Brasileira. Vol. 2. São Paulo: Livraria Martins Editora, 1969.

On literature and society. Translated, edited, and introduced by Howard S. Becker. Princeton, N.J.: Princeton New Jersey Press, 1995.

CHALHOUB, Sidney. Machado de Assis: historiador. São Paulo: Companhia das Letras, 2003.

CONY, Carlos Heitor. Confluências. In: Cadernos de literatura Brasileira: Machado de Assis. Rio de Janeiro: Instituto Moreira Salles, 2008, p. 41-45. 
DANIEL. G. Reginald. Machado de Assis: multiracial identity and the Brazilian novelist. University Park, Pennsylvania, Penn State Press, 2014.

FISCHER, Sibylle Maria. Geography and representation in Machado de Assis. Modern language quarterly 55, no. 2, 1994, p. 191-214.

FREYRE, Gilberto. Reinterpretando José de Alencar. In: __ Vida, forma e cor. Rio de Janeiro: José Olympio, 1962. p. 115-33.

GARNER, Lydia M. State and race in the Brazilian Empire. In: Forum on public policy: a journal of the Oxford round Table, 2007, p. 1-21.

GAZZOLA, Ana Lúcia and MIRANDA, Wander Melo. Introduction. In: SANTIAGO, Silviano. Uma literatura nos trópicos: ensaios sobre dependência cultural, Rio de Janeiro: Rocco, 2000, p. 1-8.

GLEDSON, John. The deceptive realism of Machado de Assis. Liverpool Monographs in Hispanic Studies, ISSN: 3; Liverpool: Francis Cairns, 1984, p. 1-8.

HOLANDA, Aurelio Buarque de. "Linguagem e estilo de Machado de Assis." Revista do Brasil, 3rd ser., vol. 2, no. 13, 1939, p. 54-77.

JOBIM, José Luis. Machado de Assis and nationalism: The Americanas case. In: Portuguese literary \& cultural studies, special issue, The author as plagiarist: the case of Machado de Assis, nos. 13-14, 2005, p. 57-83.

KRISTAL, Efraín and José Luiz Passos. Machado de Assis and the question of Brazilian national identity. In: NAVA, Carmen and LAUERHASS JR., Ludwig. (ed.). Brazil in the making: facets of national identity. Lanham, MD.: Rowan and Littlefield Publishers, Inc., 2006, p. 17-28.

LOWE, Elizabeth. The City in Brazilian Literature. East Brunswick, N.J.: Associated Press, 1982.

LUND, Joshua. The impure imagination: toward a critical hybridity in Latin American writing. Minneapolis: University of Minnesota Press, 2006.

MACIEL, Yv Scarlett. Machado de Assis' Oliveira Twist: translation and the making of a novelist, M.A. thesis, University of North Carolina, 2007.

MERQUIOR, José Guilherme. De Anchieta a Euclides: breve história da literatura Brasileira. Rio de Janeiro: Livraria José Olympio Editôra, 1977.

OMI, Michael, and WINANT, Howard. Racial formation in the United States: from the 1960s to the 1990s. New York: Routledge, 1994.

PENNA, Camillo. Antonio Candido's critical method. Santa Barbara Portuguese studies, 1997, vol. 4.

PEREIRA, Astrojildo. Interpretações. Rio de Janeiro: Casa do Estudante do Brasil, 1944. PEREIRA, Lucia Miguel. Machado de Assis. São Paulo: Companhia Editôra Nacional, 1936.

PIZA, Daniel. The place of Machado de Assis in the present. In: The author as plagiarist, 
the case of Machado de Assis. Portuguese literary \& cultural studies, 13/14, 2005, p. 28184.

RICARDO, Cassiano. Marcha para oeste: a influência da "Bandeira" na formação social e política do Brasil (2 vols). Vol. 2. Rio de Janeiro: Livraria José Olympio Editora, 1959.

REIS, Ricardo. The pearl necklace: toward an archaeology of Brazilian transition discourse. Translated by Aparecida de Godoy Johnson. Gainesville: University Press of Florida, 1992.

REGO, José Lins do. Conferências no prata: tendências do romance Brasileiro. Rio de Janeiro: Casa do Estudante do Brasil, 1946.

ROMERO, Sílvio. Machado de Assis, estudo comparativo de literatura Brasileira. Rio de Janeiro: Laemmert, 1897.

ROUANET, Sergio Paulo. 2005. The Shandean form: Laurence Sterne and Machado de Assis. The author as plagiaris, the case of Machado de Assis. Portuguese literary \& cultural studies, 13/14, 2005, p. 81-103.

SANTIAGO, Silviano. O entre-lugar no discurso Latino-Americano. In: Uma literatura nos trópicos: ensaios sobre dependência cultural. São Paulo: Perspectiva, 1978, p. 9-26.

The space in-between: essays on Latin American culture. Ana Lúcia Gazzola, (ed.). Durham, N.C.: Duke University Press, 2001.

SCHWARZ, Roberto. Ao vencedor as batatas. São Paulo: Duas Cidades, 1977.

Um mestre na periferia do capitalismo: Machado de Assis. São Paulo: Duas Cidades, 1990.

Misplaced ideas: essays on Brazilian culture. New York: Verso, 1992. - Que horas são?, ensaios. São Paulo: Schwarcz, 1987.

SHOHAT, Ella and STAM, Robert. Unthinking Eurocentrism: multiculturalism and the media. New York: Routledge, 1994.

VAL, Waldir Ribeiro do. Geografia de Machado de Assis. Rio de Janeiro: Livraria São José, 1977.

VERÍSSIMO, José. História da literatura Brasileira: de Bento Teixeira (1601) a Machado de Assis (1908). $4^{\mathrm{a}}$ ed. Brasília: UnB (Biblioteca Básica Brasileira), 1916/1963.

WHALEN, Tracy. Introduction: rhetoric as liminal practice. RHETOR, vol. 1, 2004. Available at <http://www.cssr-scer.ca/wp-content/uploads/2012/10/Rhetor1_Whalene.pdf.> Accessed: September 10, 2014.

WILLIAMS, Patrick and CHRISMAN, Laura. Colonial discourse and post-colonial theory: an introduction. In: WILLIAMS, Patrick and CHRISMAN, Laura Chrisman (ed.). Colonial discourse and post-colonial theory: a reader. New York: Columbia University Press, 1994, p. 1-19. 
G. REGINALD DANIEL is a Professor in the Department of Sociology at the University of California, Santa Barbara. His recent publications include: Machado de Assis: multiracial identity and the Brazilian novelist. University Park, Pennsylvania: Penn State University Press, 2012; "Competing narratives in the Brazilian racial order: race and multiraciality", with A. Lee. In Global Mixed Race. R. King-O'Riain, M. Mahtani, M. Song, P. Spickard, and S. Small (eds.). New York: NYU Press, 2014. p. 91-118; "Race and multiraciality: from Barack Obama to Trayvon Martin." In Race and the Obama phenomenon: the vision of a more perfect multiracial union. G. Reginald Daniel and $\mathrm{H}$. Williams (eds.). Jackson, Mississippi: The University Press of Mississippi, 2014. p. 3-40; "Emerging paradigms in critical mixed race studies", with L. Kina, W. Dariotis, and C. Fojas. Journal of critical mixed race studies 1(1) (2014), p. 7-62. $<$ rdaniel@soc.ucsb.edu>

Recebido: 14.09 .14

Aprovado: 30.10 .14 